\title{
Toxoplasmosis reactivation following HAART introduction associated with foetal death in a severely immune suppressed HIV-infected woman: an immune reconstitution inflammatory syndrome (IRIS) consequence?
}

Fabienne Caby*1, Delphine Lemercier², Fériel Touafek ${ }^{3}$, Luc Paris ${ }^{3}$, Romulus Grigorescu ${ }^{4}$, Marie Gonzales ${ }^{4}$, Guislaine Carcelain ${ }^{5}$, Michèle Pauchard ${ }^{1}$, Ana Canestri ${ }^{1}$, Christine Katlama1, Marc Dommergues ${ }^{2}$ and Roland Tubiana ${ }^{1}$

Address: ${ }^{1}$ Department of Infectious Diseases, Pitié-Salpêtrière hospital, Paris, France, ${ }^{2}$ Department of Obstetrics, Pitié-Salpêtrière hospital, Paris, France, ${ }^{3}$ Department of Parasitology, Pitié-Salpêtrière hospital, Paris, France, ${ }^{4}$ Department of Fetopathology, Trousseau hospital, Paris, France and ${ }^{5}$ Department of Immunology, Pitié-Salpêtrière hospital, Paris, France

* Corresponding author

from Fourth Dominique Dormont International Conference. Host-Pathogen Interactions in Chronic Infections Paris, France. 13-15 December 2007

Published: 9 April 2008

Retrovirology 2008, 5(Suppl I):O9 doi:10.1 I86/I742-4690-5-SI-O9

This abstract is available from: http://www.retrovirology.com/content/5/SI/O9

(c) 2008 Caby et al.; licensee BioMed Central Ltd.

\section{Background}

Congenital toxoplasmosis usually results from acquired infection in non-immune pregnant woman. Some cases have been described in immunodeficient women, as a result of Toxoplasma gondii infection reactivation [1-3]. We report the case of a fetal death probably related to a congenital toxoplasmosis in an HIV infected pregnant woman during immune restoration following HAART initiation.

\section{Case report}

An HIV infection was diagnosed in a 26 years old African pregnant woman at 10 weeks of pregnancy. The CD4 cell count was $7 / \mu \mathrm{l}(1 \%)$, the HIV viral load was $108,000 \mathrm{cp} /$ $\mathrm{ml}$, and the toxoplasmic serology was positive for IgG (18000 UI/ml) and IgM negative, the retrospective toxoplasma detection by PCR was negative at entry.

HAART consisting in a combination of lopinavir/ $\mathrm{r}$ and zidovudine plus lamivudine was introduced at 12 weeks of pregnancy resulting in a rapid immune restoration 2 weeks later: At that time the CD4 cell count increased up to $185 / \mu l(10 \%)$ and the plasmatic HIV viral load dropped to $1,222 \mathrm{cp} / \mathrm{ml}$.

A miscarriage occured 7 weeks after HAART introduction. At this time, toxoplasma PCR was positive in the mother plasma as well as in the amniotic fluid, concomitantly with an anti toxoplasma IgG increase $(81,000 \mathrm{UI} / \mathrm{ml})$ and occurrence of anti toxoplasma IgM, amniotic fluid HIV viral load was undetectable. The post-mortem analysis dated the foetus death around 16 weeks of pregnancy that was 4 weeks after the HAART introduction and showed evidence of non specific inflammatory histologic lesions.

\section{Conclusions}

The chronological parallelism between toxoplasmosis reactivation and rapid CD4 cell count increase makes us wonder if this miscarriage case could not be an immune reconstitution inflammatory syndrome manifestation associated with toxoplasmosis reactivation. According to this hypothesis, we should take into account IRIS risk factors in HIV infected pregnant woman when introducing 
HAART, not only for the mother but also for a healthy foetal development.

\section{References}

I. Bachmeyer C, Mouchnino G, Thulliez P, Blum L: Congenital toxoplasmosis from an HIV-infected woman as a result of reactivation. Journal of Infection 2006, 52:e55-e57.

2. Marty P, Bongain A, Rahal A, Thulliez P, Wasfi D, Lambert JC, Le Fichoux Y, Gillet JY: Prenatal diagnosis of severe fetal toxoplasmosis as a result of reactivation in an HIV I seropositive woman. Prenat Diagn 1994, 14:414-415.

3. Marty P, Bongain A, Loiseau S, Benoit B, Chevallier A, Gillet JY, Le Fichoux $Y$ : Lethal congenital toxoplasmosis resulting from reactivation of toxoplasmosis in a pregnant HIV-positive patient. Presse Med 2002, 31:1558.

Publish with Bio Med Central and every scientist can read your work free of charge

"BioMed Central will be the most significant development for disseminating the results of biomedical research in our lifetime."

Sir Paul Nurse, Cancer Research UK

Your research papers will be:

- available free of charge to the entire biomedical community

- peer reviewed and published immediately upon acceptance

- cited in PubMed and archived on PubMed Central

- yours - you keep the copyright

Submit your manuscript here:

http://www.biomedcentral.com/info/publishing_adv.asp 